\title{
SCIENTIFIC NOTE New Record of Scale Insects (Hemiptera: Coccoidea) as Pests of Papaya in Brazil
}

\author{
David dos S. Martins ${ }^{1,2}$, Mark P. Culik ${ }^{1,3}$ and Vera R. dos S. WolfF ${ }^{4}$ \\ ${ }^{1}$ Instituto Capixaba de Pesquisa, Assistência Técnica e Extensão Rural - INCAPER, C. postal 391, 29901-970 Vitória ES; \\ ${ }^{2}$ davidmartins@incaper.es.gov.br; ${ }^{3}$ markculik@hotmail.com; ${ }^{4}$ Fundação Estadual de Pesquisa Agropecuária FEPAGRO, \\ Rua Gonçalves Dias, 570, (Menino Deus), 90130-060, Porto Alegre, RS, e-mail: vera-wolff@fepagro.rs.gov.br
}

Neotropical Entomology 33(5):655-657 (2004)

Novo Registro de Cochonilhas (Hemiptera: Coccoidea) Como Pragas do Mamoeiro no Brasil

RESUMO - É registrada pela primeira vez a ocorrência de Coccus hesperidum L., 1758 e Aonidiella comperei McKenzie, 1937 em mamoeiro no estado do Espírito Santo e de A. comperei e Selenaspidus articulatus (Morgan, 1889) em mamoeiro no estado do Rio Grande do Norte. Destaca-se que o registro de A. comperei e S. articulatus é o primeiro em mamoeiro no Brasil e o de S. articulatus é o primeiro registro em mamoeiro no mundo.

PALAVRAS-CHAVE: Coccus hesperidum, Aonidiella comperei, Selenaspidus articulatus, Carica papaya

ABSTRACT - The occurrence of Coccus hesperidum L., 1758 and Aonidiella comperei McKenzie, 1937 was registered for the first time on papaya in the state of Espírito Santo, Brazil. Also A. comperei and Selenaspidus articulatus (Morgan, 1889) were registered on papaya in the state of Rio Grande do Norte. This is the first record of A. comperei and S. articulatus on papaya in Brazil, and the first record of $S$. articulatus on papaya in the world.

KEY WORDS: Coccus hesperidum, Aonidiella comperei, Selenaspidus articulatus, Carica papaya

As part of efforts for development of integrated production of papaya, Carica papaya L., in Brazil (Martins et al. 2003), insect surveys were conducted in commercial orchards and experimental plantings in Espírito Santo, Brazil, in order to identify pests of papaya in this area, with additional collections made in Rio Grande do Norte. In this research, two scale insects (Hemiptera: Coccoidea), Aonidiella comperei McKenzie, 1937 and Selenaspidus articulatus (Morgan, 1889) (Diaspididae), not previously reported as pests of papaya in Brazil were found. Information on an additional scale insect species found on papaya in this research, Coccus hesperidum L., 1758 (Coccidae), is also presented (Table 1).

C. hesperidum was found in one sample collected from the stem of papaya growing in a research greenhouse in Sooretama municipality, Espírito Santo, in December 2002. This species was also identified in samples collected from papaya from two field sites in Linhares municipality, Espírito Santo in 1999 (D. Miller, Systematic Entomology Laboratory, Beltsville, pers. comm.). In addition, the presence of Coccus species was confirmed on papaya from three other field sites in the same area (Linhares and Sooretama municipalities).

A. comperei was found in two samples of the fruit and trunk of papaya collected from one commercial papaya orchard in Linhares municipality, Espírito Santo in November 2002.
This species was also found on fruit and stem of papaya collected from a commercial papaya orchard in Linhares municipality, Espírito Santo in 1999 (D. Miller, Systematic Entomology Laboratory, Beltsville, pers. comm.). A. comperei was also present on papaya fruit collected from field sites in the municipalities of Parnamirim and Ceará Mirim, Rio Grande do Norte in January 2003, and was identified on the fruit and trunk of papaya collected in Pinheiros municipality, Espírito Santo in February 2003. In additional collections made in February 2004, A. comperei was found on papaya fruit from three additional commercial papaya orchards in Linhares municipality, Espírito Santo, and two additional sites in Rio Grande do Norte, including Ceará Mirim and the municipality of Maxaranguape where the species was also found on the trunk of papaya. With A. comperei, S. articulatus was also found on the papaya fruit that was collected from Ceará Mirim, Rio Grande do Norte in January 2003 (Table 1).

Voucher specimens of these insects are deposited in the arthropod collections of INCAPER, Vitória, Espírito Santo and Fundação Estadual de Pesquisa Agropecuária FEPAGRO, Museu de Entomologia Professor Ramiro Gomes Costa, Porto Alegre, Rio Grande do Sul (dates of collection are listed in Table 1).

The collections and identifications reported here are the 
Table 1. Records of Coccidae and Diaspididae collected from papaya in Espiríto Santo and Rio Grande do Norte, Brazil.

\begin{tabular}{|c|c|c|c|c|}
\hline Species & $\begin{array}{c}\mathrm{N}^{0} \text { samples } \\
\text { observed }\end{array}$ & $\begin{array}{l}\text { Collection } \\
\text { locations }\end{array}$ & Location on plant & Dates collected; depository location ${ }^{1}$ \\
\hline \multicolumn{5}{|l|}{ Coccidae } \\
\hline Coccus sp. & 9 & $\begin{array}{l}\text { Linhares-ES, } \\
\text { Sooretama-ES }\end{array}$ & $\begin{array}{l}\text { On papaya fruit and } \\
\text { stem }\end{array}$ & $\begin{array}{l}24 \text { Sep } 2002,1 \text { Oct } 2002,6 \text { Nov } \\
\text { 2002, } 9 \text { Nov 2002, } 19 \text { Nov 2002, } 05 \\
\text { Dec 2002; INCAPER }\end{array}$ \\
\hline C. hesperidum & 3 & $\begin{array}{l}\text { Linhares-ES, } \\
\text { Sooretama-ES }\end{array}$ & On papaya stem & 5 Dec 2002; INCAPER \\
\hline \multicolumn{5}{|l|}{ Diaspididae } \\
\hline \multirow[t]{6}{*}{ A. comperei } & 3 & Linhares-ES & $\begin{array}{l}\text { On papaya fruit, trunk } \\
\text { and stem }\end{array}$ & $\begin{array}{l}12 \text { Nov 2002; FEPAGRO, } \\
\text { INCAPER }\end{array}$ \\
\hline & 2 & Pinheiros-ES & $\begin{array}{l}\text { On papaya fruit and } \\
\text { trunk }\end{array}$ & 25 Feb 2003; FEPAGRO, INCAPER \\
\hline & 11 & Linhares-ES & On papaya fruit & $\begin{array}{l}10 \text { Feb 2004, } 12 \text { Feb 2004, } 26 \text { Feb } \\
\text { 2004; FEPAGRO, INCAPER }\end{array}$ \\
\hline & 2 & $\begin{array}{l}\text { Ceará Mirim-RN, } \\
\text { Parnamirim-RN }\end{array}$ & On papaya fruit & $\begin{array}{l}29 \text { Jan } 2003 \text {, } 30 \text { Jan } 2003 \text {; } \\
\text { FEPAGRO }\end{array}$ \\
\hline & 1 & Ceará Mirim-RN, & On papaya fruit & 18 Feb 2004; FEPAGRO, INCAPER \\
\hline & 2 & $\begin{array}{l}\text { Maxaranguape- } \\
\text { RN, }\end{array}$ & $\begin{array}{l}\text { On papaya fruit and } \\
\text { trunk }\end{array}$ & 19 Feb 2004; FEPAGRO, INCAPER \\
\hline S. articulatus & 1 & Ceará Mirim-RN & On papaya fruit & 30 Jan 2003; FEPAGRO \\
\hline
\end{tabular}

${ }^{1}$ INCAPER = Instituto Capixaba de Pesquisa, Assistência Técnica e Extensão Rural - INCAPER, Vitória, ES; FEPAGRO = Fundação Estadual de Pesquisa Agropecuária - FEPAGRO, Museu de Entomologia Professor Ramiro Gomes Costa, Porto Alegre, RS

first record of the scale insect species $C$. hesperidum and $A$. comperei on papaya in the state of Espírito Santo and, the first record of the species A. comperei and $S$. articulatus on papaya in the state of Rio Grande do Norte. It is also the first record of the species A. comperei and S. articulatus on papaya in Brazil and, the first record of the species $S$. articulatus on papaya in the world.

Worldwide, at least 43 species of scale insects were recorded as pests of papaya of which about half ( 27 species) are known to occur in Brazil and eight were previously recorded on papaya in this country (Silva et al. 1968, Medina et al.1989, Pantoja et al. 2002, Culik et al. 2003).

C. hesperidum is one of the most cosmopolitan, widely distributed and most broadly polyphagous soft scale insects. Because of its broad host range it is a common agricultural pest and it is commonly known as the "brown soft scale" or "escama marrom". This species was previously reported as a pest of papaya in Florida and Hawaii (Culik et al. 2003). In Brazil, C. hesperidum was recorded from the states of Amazonas, Bahia, Pará, Rio de Janeiro, Rio Grande do Sul, Santa Catarina and São Paulo and noted on papaya (Silva et al. 1968). In addition to C. papaya, C. hesperidum occurs on at least 40 other plant hosts in Brazil (Silva et al.1968).

A. compere $i$ is widespread and has been recorded from areas in Asia and the Pacific, Central and South America, and the Caribbean. The species also has a broad host range including citrus and a variety of other agricultural crops. A. comperei is known as a pest of papaya in the Pacific Islands (Pantoja et al. 2002). In Brazil this species was recorded from the states of Alagoas, Paraíba, Pernambuco and Rio de Janeiro but it was not reported as a pest of papaya (Silva et al. 1968). Other hosts of $A$. comperei in Brazil are Citrus medica var. acida, Citrus sinensis, Melissa officinalis, Musca sp., Musca sapientum, Ricinus communis, Rosa sp., Tamarindus indica, Vitis spp., and Vitus vinifera (Silva et al. 1968, Claps et al.2001).

S. articulatus is a cosmopolitan species known from North, South and Central America, the Caribbean, and Africa, Asia, Australia and Europe. This species is considered exotic to Brazil but was already recorded from the states of Bahia, Espírito Santo, Pará, Rio de Janeiro and São Paulo on a wide variety of agricultural crops and it is commonly known as the "cochonilha-pardinha" (Silva et al. 1968, Claps et al. 2001, Loayza \& Parra 2001). S. articulatus has been found on at least 22 plant species in Brazil (Silva et al. 1968, Claps et al. 2001, Loayza \& Parra 2001) but has not on papaya (Pantoja et al. 2002, Culik et al.2003).

By feeding on plants, scale insects such as $C$. hesperidum, A. comperei and $S$. articulatus cause leaf yellowing, defoliation, and reduced plant vigor and fruit set. In addition, secretion of honeydew by $C$. hesperidum contributes to the development of sooty mold that decreases photosynthesis and reduces the marketability of fruit (Beardsley \& Gonzalez 1975, Elmer \& Brawner 1975, Copland \& Ibrahim 1985). Besides direct and indirect damage to plants and fruit, scale insects are also of quarantine concern, adding to costs of production to prevent or eliminate their presence on plants, and in some cases preventing exportation of fruits such as papaya.

The records reported here indicate that the scale insects C. hesperidum, A. comperei and S. articulatus are potentially important pests of papaya in Brazil warranting additional research on these species. 


\section{Acknowledgments}

We thank J.S. Andrade, V.R. Cordoso, and A.O.F. Couto, M. Deusdete, J.R.M. Fontes, R.C.A. Lima, and L.F. de Mendonça for collecting, and D. Miller for identifying scale insects reported in this publication. We also thank B.E.V. Pacova and J.A. Ventura, INCAPER, for helpful suggestions in reviewing this publication. The Conselho Nacional de Desenvolvimento Científico e Tecnológico - CNPq provided financial support for this work.

\section{Literature Cited}

Beardsley, J.W. Jr. \& R.H. Gonzalez. 1975. The biology and ecology of armored scales. Annu. Rev. Entomol. 20: 47-73.

Claps, L.E., V.R.S. Wolff \& R.H. González. 2001. Catálogo de las Diaspididae (Hemiptera: Coccoidea) exóticas de la Argentina, Brasil y Chile. Rev. Soc. Entomol. Argent. 60: 9-34.

Copland, M.J.W. \& A.G. Ibrahim. 1985. Biology of glasshouse scale insects and their parasitoids, p. 87-90. In N.W. Hussey $\&$ N. Scopes. Biological pest control: The glasshouse experience. Ithaca, Cornell University Press, 240p.

Culik, M.P., D. dos S. Martins \& J.A. Ventura. 2003. Índice de artrópodes pragas do mamoeiro (Carica papaya L.). Vitória, INCAPER, 48p.

Elmer, H.S. \& O.L. Brawner. 1975. Control of brown soft scale in Central Valley. Citrograph 60: 402-403.
Loayza, R.M. \& J.R.P. Parra. 2001. Cochonilha-pardinha, Selanaspidus articulatus (Hemiptera: Diaspididae), p. 53-57. In E.F. Vilela, R.A. Zucchi \& F. Cantor (eds.). Histórico e impacto das pragas introduzidas no Brasil. Ribeirão Preto, Holos, 173p.

Martins, D. dos S., O.K. Yamanishi \& J. da S. Tatagiba. 2003. Normas técnicas e documentos de acompanhamento da produção integrada de mamão (Documentos, 120). Vitória, INCAPER. 60p.

Medina, J.C., E.W. Bleinroth, J.M.M. Sigrist, Z.J. de Martin, A.L.A.C. Niscida, V.L.S.

Baldini, R.S.S.F. Leite \& A.E.B. Garcia. 1989. Mamão: Cultura, matéria-prima, processamento e aspectos econômicos, 2 ${ }^{\mathrm{a}}$. ed. rev. ampl. Campinas, ITAL, 367p.

Pantoja, A., P.A. Follett, \& J.A. Villanueva-Jiménez. 2002. Pests of papaya, p. 131-156. In J. Pena, J. Sharp \& M. Wysoki (eds.). Tropical fruit pests and pollinators: Biology, economic importance, natural enemies and control. Cambridge, CABI Publishing, 448p.

Silva, A.G.A., C.R. Gonçalves, D.M. Galvão, A.J.L. Gonçalves, J. Gomes, M. do N. Silva \& L. de Simoni. 1968. Quarto catálogo dos insetos que vivem nas plantas do Brasil seus parasitos e predadores. Parte II $-1^{\circ}$ Tomo. Rio de Janeiro, Ministério da Agricultura, $622 \mathrm{p}$.

Received 30/09/03. Accepted 01/04/04. 